\title{
STUDI BENTUK DAN ELEMEN ARSITEKTUR MASJID DI JAKARTA DARI ABAD 18 - ABAD 20
}

\author{
Widya Katarina \\ Architecture Department, Faculty of Engineering, Binus University \\ Jl. K.H. Syahdan No. 9, Palmerah, Jakarta Barat 11480 \\ w.katarina@yahoo.com
}

\begin{abstract}
Modern and traditional mosques in Jakarta have differences triggered by the growing progress of time. Nevertheless, the basic elements of the mosques, such as a floor plan of the main room is square-shaped, do not change a lot. No matter what the forms are, the main function of a mosque is for praying. This study discusses about the forms of mosques in Jakarta from the 18th century - 20th century.
\end{abstract}

Keywords: form of mosque, basic elements of mosque

\begin{abstract}
ABSTRAK
Masjid modern dan masjid tradisional di Jakarta mempunyai perbedaan-perbedaan yang dipicu oleh kemajuan zaman. Tetapi elemen-elemen dasar masjid-masjid ini tidak banyak mengalami perubahan, seperti bentuk denah ruang utama masjid yang mayoritas berbentuk persegi. Bagaimanapun bentuknya, fungsi utama masjid yaitu untuk melaksanakan ibadah shalat. Studi ini akan membahas bentuk-bentuk masjid yang ada di Jakarta dari abad 18 - abad 20.
\end{abstract}

Kata kunci: bentuk masjid, elemen-elemen dasar masjid 


\section{PENDAHULUAN}

Keragaman Indonesia menjadi buku terbuka bagi dunia. Setiap orang ingin datang melihat dan mempelajari. Salah satu unsur yang ingin saya bahas ialah agama. Di Indonesia khususnya, keberadaan agama sendiri telah dipengaruhi oleh adat istiadat. Islam sebagai agama besar di Indonesia juga mengalami hal ini. Sejak masuk di Indonesia, unsur-unsur Islam telah mengalami perubahanperubahan yang disebabkan oleh pengaruh adat istiadat, budaya, dan agama lain yang sudah lebih dahulu dikenal oleh masyarakat Indonesia. Pengaruh ini tidak hanya dalam hal praktek saja, tetapi juga dapat dilihat pada rumah ibadah, yaitu masjid.

Masjid berasal dari bahasa Arab yang mempunyai pengertian bahwa masjid sama halnya dengan bangunan sebuah gedung dalam bentuk yang khas. Akan tetapi sesungguhnya dalam Islam, pengertian tentang masjid tidaklah sempit dan kaku, sebagaimana anggapan kita selama ini. Sesuai makna harafiahnya, pengertian tentang masjid tetap tempat sujud. Hal ini tercermin dari sebuah hadits Rasulullah SAW yang diriwayatkan oleh Tirmuzy dari Abi Sa'id al Kudry, mengatakan: "Telah dijadikan tanah itu bagiku sebagai tempat sujud". Jadi, di sini pengertian tentang masjid itu secara mutlak hanyalah tempat sujud bagi umat Islam dalam rangka memanifestasikan dirinya sebagai makhluk Allah.

Kata "masjid" menurut istilah lidah dan dialek Indonesia sering disebut dengan "mesjid". Di beberapa daerah, sebutan itu pun beraneka ragam sesuai dengan bahasa dan dialektika daerah tersebut (Ensiklopedia Indonesia, 1990). Misalnya di Jawa, banyak orang yang menyebutnya dengan "mesigit", di Sunda disebut "masigit". Sedangkan dalam bahasa Inggris diterjemahkan sebagai "mosque" atau Belanda menyebutnya "mooske". Demikianlah masjid secara berkesinambungan terus dibangun bersamaan dengan berkembangnya agama Islam di seluruh pelosok dunia. Sebuah masjid hadir di tengah umat Islam disamping tempat sujud menyerahkan diri kepada Allah, juga sebagai sarana untuk mempersatukan umat dalam rangka menggalang kemajuan Islam di masa yang akan datang.

Masjid tempat menenangkan pikiran, menjernihkan keruwetan hidup dan membuang semua rasa emosional pribadi untuk kemudian mawas diri, menyadari semua kekurangan dan kelemahan diri dihadapan Allah SAW. Masjid sebagai pemersatu umat, jelas mengemban suatu peran yang tidak kecil bagi kemajuan Islam. Karena dalam masjid inilah dilakukan sembahyang berjamaah yang merupakan manifestasi dari rasa kesatuan, satu dalam sikap, satu dalam derajat dan satu dalam tujuan.

Pada dasarnya masjid mempunyai fungsi ganda, yaitu sebagai pusat ibadah sekaligus juga sebagai pusat muamalah. Masjid dibangun sebagai ujung pembinaan ibadah juga awal pembinaan muamalah (sosial kemasyarakatan). Masjid yang kita lihat sekarang ini telah mengalami banyak perubahan dari masjid pada awalnya. Waktu, adat istiadat, iklim, budaya, dan hAl-hal lainnya telah merubah bentuk masjid. Sehingga lahir bentuk masjid yang beragam dan tersebar di seluruh Indonesia. Bagaimana proses perubahan bentuk-bentuk masjid tersebut merupakan hal menarik untuk dipelajari lebih lanjut.

\section{METODE}

Kajian ini menggunakan metode deskriptif dengan tujuan untuk menemukan dan menggambarkan bentuk-bentuk bangunan masjid abad 18 - abad 20. Lokasi penelitian mengambil bangunan-bangunan masjid yang berada di Jakarta. Untuk mendapatkan data-data yang dibutuhkan, dilakukan cara pengumpulan data melalui metode survei, pengamatan dan studi literatur tentang masjid-masjid di Jakarta dikaitkan dengan kajian teori mengenai bentuk dan elemen arsitektur masjid. 
Analisis data dilakukan dengan membandingkan teori terkait desain masjid dengan kondisi di lapangan dari berbagai masjid di Jakarta yang dijadikan obyek studi.

\section{HASIL DAN PEMBAHASAN}

\section{Elemen-elemen Masjid}

\section{Minaret}

Minaret adalah menara yang letaknya di dekat/dibangun pada struktur sebuah masjid, yang digunakan oleh muazin ( juru azan) untuk mengumandangkan adzan yang mengajak umat muslim untuk berdoa/sembahyang (Hillebrand Robert, 1998). Pada mulanya masjid dibangun tanpa minaret dan adzan dapat dikumandangkan dari berbagai lokasi. Minaret pertama terletak antara Kairo, Tunisia, dan Damaskus, Syria.

Sekarang minaret menjadi simbol Islam namun bukan simbol yang dalam secara teologi. Minaret modern menyediakan ruang lebih untuk hAl-hal yang bersifat artistik. Lantai dasar minaret selalu berbentuk kotak/persegi dan menaranya dapat berbentuk bermacam-macam dari persegi hingga lingkaran namun kebanyakan berbentuk oktagonal. Puncak dari bangunan ini merupakan tempat di mana muazin ataupun alat pengeras suara (loudspeaker) mengumandangkan adzan.

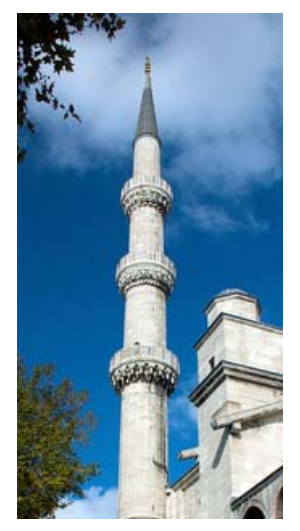

Gambar 1. Minaret Blue Mosque, Istanbul (Sacred Ddestinations, 2009).

\section{Mihrab}

Mihrab dalam masjid yang mengindikasikan kiblat (menunjukkan ke mana arah para muslim harus sembahyang/shalat). Mihrab merupakan posisi dari orang yang memimpin konggregasi dalam masjid. Normalnya dalam masjid terdapat hanya satu mihrab. Kemungkinan mihrab mulai diperkenalkan pada abad ke-3 Islam, yaitu pada abad ke-9 M. Mihrab dapat terbuat dari kayu tetapi normalnya terbuat daru masonry dan dihias dengan pilar-pilar.

\section{Mimbar}

Mimbar (Gambar 2).dalam masjid letaknya di samping mihrab. Mimbar merupakan tempat khatib berkotbah pada hari Jumat, atau saat Jumatan. Mimbar kemudian mempunyai fungsi yang cukup penting untuk komunikasi. 


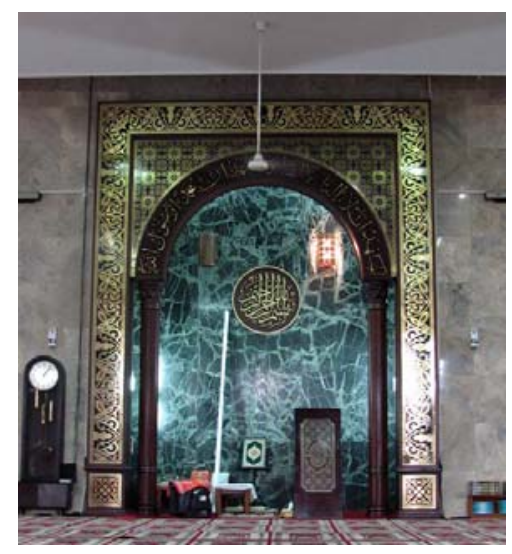

Gambar 2. Mimbar Masjid Agung Sunda Kelapa (Gunawan, 2011).

Tampilan mimbar kemungkinan mengekspresikan posisi rasul/nabi dalam masyarakat, di mana mimbar berfungsi sebagai tahta. Mimbar rasul/nabi ini memiliki tidak lebih dari dua anak tangga dan sebuah tempat duduk. Seorang Caliph Mu'awiyya yang hidup pada $670 \mathrm{M}$ mendirikan mimbar bagi Muhammad yang terdiri dari enam anak tangga dan ini menjadi pola bagi semua mimbar selanjutnya (George Michell, 1995).

Mimbar dapat ditemukan pada masjid disemua propinsi sejak sebelum tahun 700 M. Dan pada beberapa masjid ditemukan lebih dari satu mimbar. Kemudian mimbar ditutupi dengan tabir yang mengambil contoh dari Ka'ba.

\section{Muazin}

'Pemanggil' dalam Islam, yaitu orang yang memanggil umat muslim untuk menjalankan shalat. Di banyak masjid, muazin melakukan panggilan dengan adzan dari minaret, tapi banyak juga masjid yang menggunakan pengeras suara di atas minaret.

Muazin pertama menggunakan tempat, yaitu atap dari masjid atau di muka jalan-jalan untuk melakukan panggilan tersebut.

\section{Dakka}

Dakka ialah sebuah pijakan di mana muazin melakukan panggilan untuk shalat setelah melaksanakan adzan dari minaret. Selain elemen-elemen di atas, terdapat pula sebuah meja dengan sebuah tempat duduk untuk Al-Quran dan pembacanya. Serta lampu/penerangan dari lilin maupun lampu untuk pencahayaan tapi bukan suatu ritual.

\section{Bentuk Bangunan Masjid di Jakarta Abad ke-17}

Masjid pertama di Jakarta pada tahun 1619 terletak di beberapa puluh meter di sebelah selatan Hotel Omni Batavia, yaitu antara jalan Kali Besar Barat dan jalan Roa Malaka Utara, di daerah Kota. Bangunan masjid ini bergaya Jawa dan dibangun/terbuat dari kayu.

\section{Masjid Al-Alam (Jalan Cilincing Lama II)}

Ruang utama masjid ini berukuran 10x10 m, yaitu ruang di bawah atap tumpang dua yang puncaknya dihiasi memdo. Inilah bagian tertua yang memadukan gaya Jawa dan unsur Moor. Tembok 
setinggi satu meter dibuat dari batu, sedangkan untuk bagian atas digunakan konstruksi kayu serta gedek untuk dinding. Atap ditopang oleh emapt batang kayu jati setinggi tujuh meter. Mihrab terletak di sisi barat dan agak menjorok keluar. Konstruksi asli ini masih dipertahankan waktu masjid ini dipugar (1972-1989), tetapi diperluas dengan menambahkan serambi.

\section{Masjid Al-Alam (Kampung Marunda Besar)}

Unsur-unsur tua dalam masjid ini antara lain: empat sokoguru serta tiga tiang semu yang menempel pada dinding yang dihiasi dengan pelipit dan tubuhnya dengan jalur-jalur vertikal. Denah dasar ruang paling tua bersegi empat (8x8 $\mathrm{m}$ ); atap bergaya tradisional Jawa; limasan dan tumpang dua. Jendela tak berdaun namun bidangnya diisi teralis kayu bulat yang bergelombang dan dihiasi pelipit kedua serambi ditambah di kemudian hari.

\section{Masjid Ash-Shalafiah}

Masjid ini dibangun oleh orang Kauman Jatinegara, keturunan beberapa pangeran Banten. Gedung masjid ini (Gambar 3) berisi sisa-sisa bangunan dari sebuah masjid yang sudah sangat tua. Bagian tertua masjid asli adalah keempat sokoguru yang terletak di tengah-tengah ruang utama.

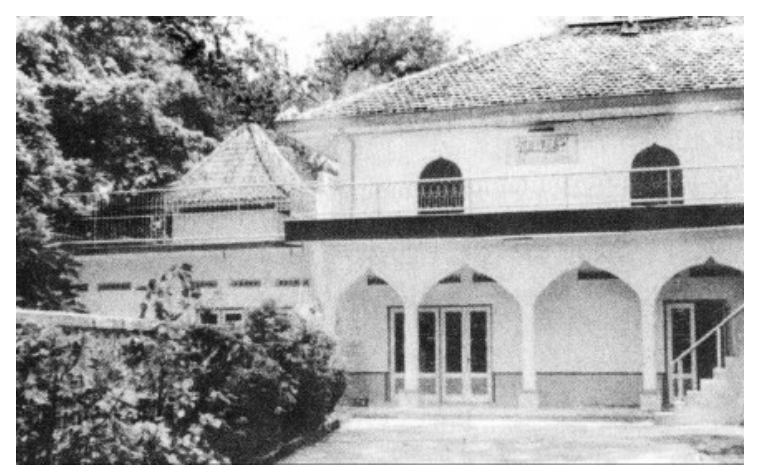

Gambar 3. Masjid Al-Shalafiah (Jakarta.go.id., 2012).

\section{Bentuk Bangunan Masjid di Jakarta Abad ke-18}

\section{Masjid Al-Mansur (1717)}

Masjid ini terletak di Jalan Sawah Lio II/33, Kampung Jembatan Lima. Ruang utama masjid ini merupakan bagian bangunan tertua berbentuk segi empat (12x14,40 m). Unsur yang mencolok adalah empat soko guru yang kokoh dan tampak kekar di tengahnya. Pada ketinggian setengah di antara empat sokoguru terdapat balok-balok kayu antara lain untuk menopang kedua tangga yang menuju ke loteng. Pola pagarnya berbentuk belah ketupat, atap masjid ini berbentuk limasan, menara yang terletak di dalam ruang baru di depan masjid lama berbentuk silinder setinggi 12m. Pada bagian keempat dan kelima dari menara itu terdapat teras yang berpagar besi. Atap menara berbentuk kubah.

\section{Masjid Luar Batang (Sebelum 1736)}

Masjid Luar Batang (Gambar 4) didirikan oleh Sayid Husein bin Abubakar bin A. Al-Aydrus. Ruang utama masjid ini berbentuk persegi empat dengan tiang penyangga yang berbentuk persegi empat polos. Serambi pada ruang utama disanggah oleh delapan tiang. Pada tahun 2002 masjid ini diperbaiki dan ada peruabahan dari masjid yang lama. Seluruh lantainya dinaikkan setinggi satu meter, 
sehingga rata dengan lantai masjid baru yang sudah dibangun di belakangnya. Hal ini dianggap perlu karena kelembaban tanah.

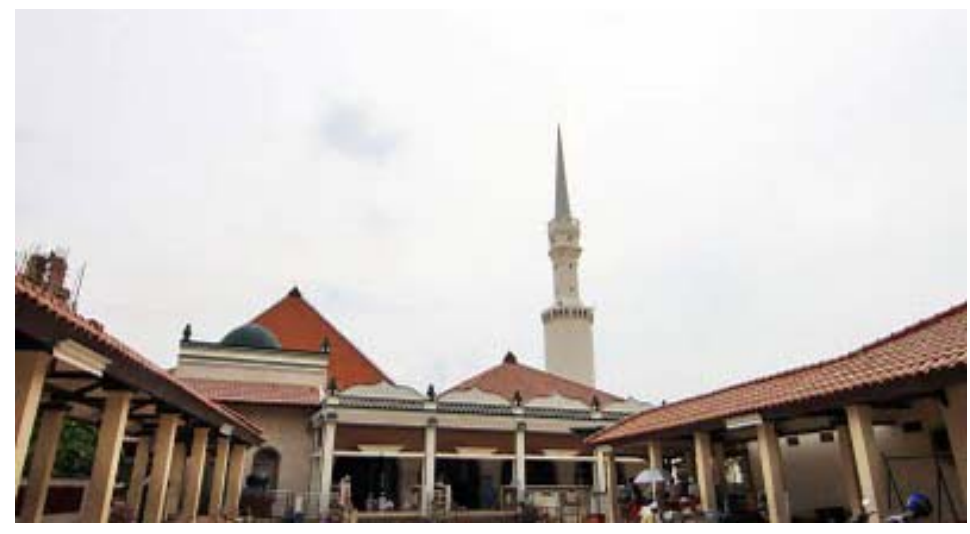

Gambar 4. Masjid Luar Batang (Gunawan, 2011).

\section{Masjid Kampung Baru (1748)}

Masjid yang terletak di Bandengan Selatan ini (Gambar 5) didirikan oleh pedagang India yang beragama Islam. Denah dasarnya berbentuk persegi, atapnya tumpang satu dengan atap corak limasan pada bagian atasnya, sedangkan limas bawah seperti terpancung sehingga digolongkan tipe masjid Jawa gaya pendopo. Di dalam masjid terdapat ukiran buah anggur yang indah.

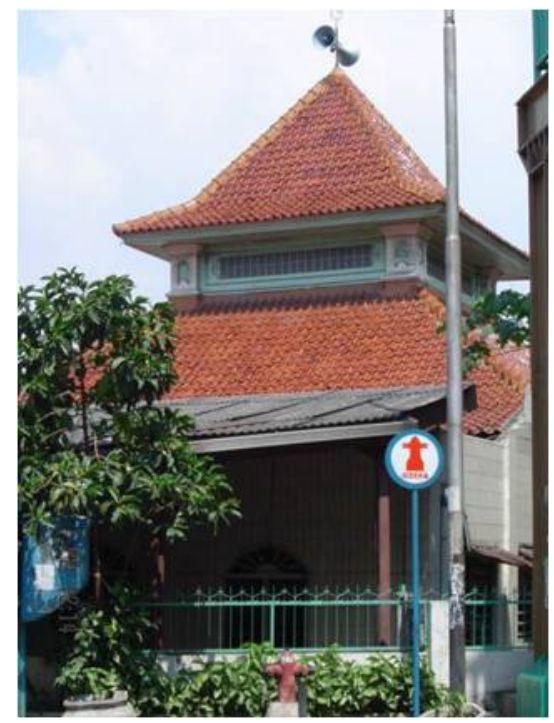

Gambar 5. Masjid Kampung Baru (Prihamdani, 2011).

\section{Masjid An-Nawier (1760)}

Masjid An-Nawier (Gamabr 6) terletak di jalan Pekojan No. 79. Yang menonjol dari masjid ini adalah menaranya yang seolah muncul dari ruang utama. Lain dari banyak menara yang berdiri di samping masjid, atap menara berbentuk kerucut yang dibuat dari 16 bilah papan. Bentuk menara memperlihatkan gaya Hadhramaut. 


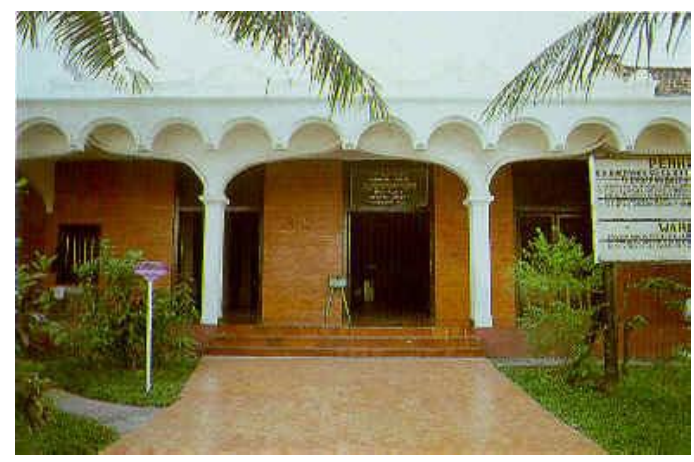

Gambar 6. Masjid an Nawier (Wisata Melayu, 2012).

\section{Masjid Angke (1761)}

Masjid Angke kini disebut Masjid Al-Anwar. Masjid ini dibangun oleh seorang kontraktor Tionghoa untuk orang Bali yang beragama Islam. Ujung-ujung atapnya sedikit melengkung ke atas, menunjuk pada punggel rumah Bali. Bentuk dasar bangunan memperlihatkan pengaruh Jawa, yaitu bujur sangkar. Lima anak tangga di depan, daun pintu ganda, lubang angin di atas pintu yang dihiasi dengan ukiran bagus, sama seperti kusen pintu dan (bekas) pot batu alam yang di pucuk atap, yang dahulu sangat umum digunakan pada rumah-rumah Belanda. Atap tumpang bersusun dua yang berbentuk limasan, puncak atap sekarang dihiasi mustika yang bercorak piala.

\section{Masjid Tambora (1761)}

Masjid yang terletak di jalan Tambora IV (Gambar 7) ini dibangun oleh orang Tionghoa muslim. Terlihat pengaruh arsitektur tionghoa yang sangat kental pada cungkup, mihrab, dan kaki sokogurunya.

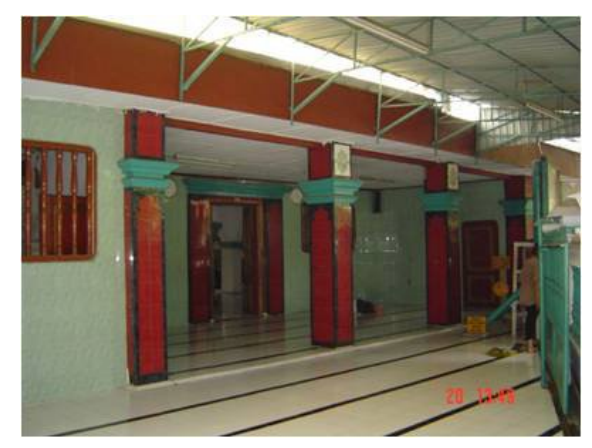

Gambar 7. Masjid Tambora (Facebook, 2010).

\section{Masjid Kebon Jeruk (1786)}

Masjid Kebon Jeruk (Gambar 8) dibangun oleh muslim Tionghoa. Ruang Utama masjid ini berukuran 10x10 m yang pada ketiga sisinya terdapat tiga pintu dengan bentuk serta ukuran yang sama, sedang pada sisi barat hanya dua. Masjid ini memiliki dua limasan atap yang berbentuk menara. Puncak atap lama berbentuk persegi empat dan seakan-akan tersembul dari tingkat kedua. Di dalam menara ini terdapat hiasan bulan bintang. Panggung di bawah atap cukup unik karena teralis kayu lama diganti dengan jendela kaca. Atap menara baru berbentuk segi delapan dan terletak di depan menara lama, atapnya berbentuk limasan. Dinding menara dihiasi dengan jendela yang melengkung. 


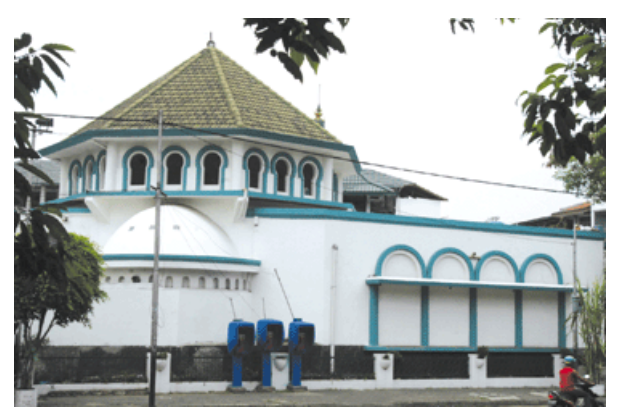

Gambar 8. Masjid Kebon Jeruk (Mesjid Jami Kebon Jeruk, 2009).

\section{Masjid Al-Mukarromah (1789)}

Masjid Al-Mukarromah (Gambar 9) didirikan di jalan Lodan (1715 makam) oleh Sayid Abdul Rahman bin Alwi as-Syathini.

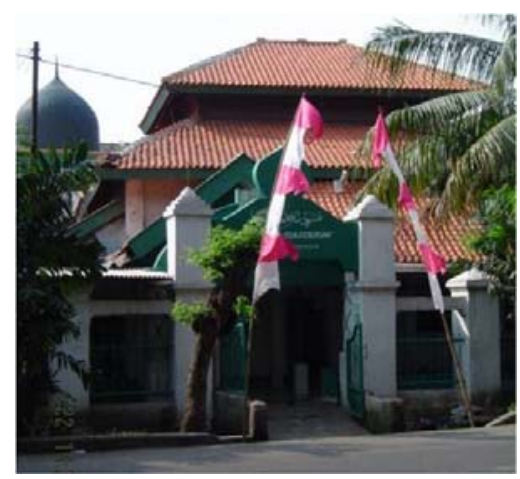

Gambar 9. Masjid Al-Mukarromah (Tarekat Qodiriyah, 2011).

\section{Bentuk Bangunan Masjid di Jakarta Abad ke-19}

\section{Masjid Al-Mukarromah (1815)}

Masjid Al-Mukarromah terletak di jalan Kali Lio. Masjid ini memadukan gaya bangunan Eropa serta Indonesia. Pada mulanya disebut Masjid Kampung Besar. Empat sokoguru yang berjajar lurus dan menupang atap terbuat dari kayu jati hitam dan nama orang yang menyumbangkannya tertera di bagian atasnya.

\section{Masjid Langgar Tinggi (1829)}

Masjid ini didirikan di kelurahan Pekojan. Masjid ini mengandung unsur-unsur arsitektur Eropa (pilar-pilar klasisistis menurut Orde Toskan), Tionghoa (penyangga balok) dan Jawa (denah dasar).

\section{Bentuk Bangunan Masjid di Jakarta Abad ke-20}

\section{Masjid Hidayatullah (1921)}

Masjid ini terletak di Karet, Kuningan. Ruang utama masjid ini berukuran 10x16.8 m, didirikan di atas pondasi setinggi $25 \mathrm{~cm}$ dan diapit oleh dua menara di bagian mukanya. Menara ini 
mungkin dipengaruhi oleh gaya Persia. Pengaruh gaya bangunan Tionghoa tampak pada bentuk atap bangunan utama dan menara, yaitu jurai atap melengkung. Pengaruh ini tampak pula pada gaya unik mimbar yang berupa hiasan flora (lotus, daun artimesia) dan fauna (burung, ayam, dan kerang).

\section{Masjid Jami Al-Makmur (sekitar 1915-1917)}

Masjid yang berada di Tanah Abang ini dibangun oleh Sayid Abubakar bin Mohammad bin Abdurachman Al-Habsi. Masjid ini dirancang oleh seorang arsitek Belanda. Pada awalnya berukuran 44x28 m. Masjid ini memiliki dua menara pendek yang mengapit tiga pintu masuk dan atap bangunan masjid ini berbentuk kubah. Gaya bangunannya menyerupai masjid Timur Tengah.

\section{Masjid Al-Makmur (1923-1924)}

Masjid Al-Makmur (Gambar 10) berada di pekarangan Raden Saleh, Cikini. Masjid ini merupakan pindahan dari sebuah mushollah/masjid sederhana dari kayu dan gedek yang ada sejak 1859 yang pernah berada dalam kebun luas pelukis termasyur Raden Saleh. Menara masjid ini 'luar' biasa untuk Jakarta karena tidak lancip ke atas melainkan berbentuk kubah.

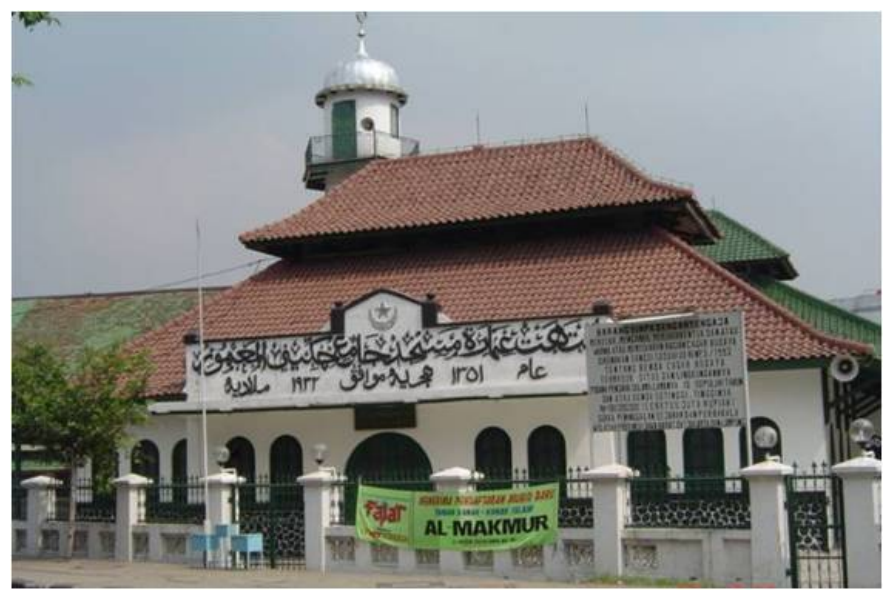

Gambar 10. Masjid Al-Makmur (Kaskus, 2011).

\section{Masjid Boplo (1985)}

Masjid ini adalah bekas kantor Bouwploeg (1912). Masjid ini dinamakan Masjid Cut Mutiah. Denah dasar bangunan ini menyerupai salib Yunani dengan keempat baloknya sama panjangnya. Menara yang persegi empat itu sedkit pendek. Tiga tingkatnya, dikelilingi empat sayap yang hanya bertingkat dua. Ruang tengah memakai seluruh tempat di bawah kubah sentral setinggi tiga tingkat. Bagian atas jendela-jendela yang setengah melengkung diisi kaca patri yang indah. Busur/lengkungan ditunjang pilaster.

\section{PENUTUP}

Pada dasarnya tidak ada peraturan pasti tentang bagaimana bentuk sebuah masjid seharusnya. Jika kita melihat ke belakang, dapat dilihat bahwa masjid pertama hanya berupa sebuah lapangan, yaitu halaman rumah Nabi Muhammad di Madinah. Di kemudian hari muncullah beberapa penambahan elemen masjid yang pada awalnya dikarenakan tuntutan fungsi, seperti atap untuk 
melindungi dari panas dan hujan; dinding untuk melindungi, memberi batas, atau menciptakan suasana yang lebih pribadi/khusuk; menara/minaret yang digunakan muazin untuk melakukan panggilan/mengumandangkan adzan; kemudian penambahan elemen air untuk para umat membersihkan diri sebelum melakukan ibadah shalat (berwudhu); sementara ornamen kaligrafi berfungsi untuk menunjukkan identitas muslim.

Seiring dengan berjalannya waktu muncullah bentuk-bentuk masjid yang beragam karena disesuaikan dengan daerah dan kebudayaan masyarakat setempat. Pembangunan masjid-masjid pada awal berkembang pesat di Timur Tengah yang terkenal dengan atap kubah dan jendela dengan bentuk lengkung sebagai ciri khasnya. Sementara bentuk masjid di Jakarta sendiri pada awalnya tidak mempunyai patokan bentuk yang jelas; karena bentuk bangunan masjid pada mulanya disesuaikan dengan bentuk rumah masyarakat pada saat itu. Yaitu bentuk sederhana dengan atap susun tumpang dua agar tidak dirasa asing, sehingga masyarakat lebih dapat menerima kebudayaan Islam yang perlahan-lahan mulai masuk ke dalam kebudayaan Indonesia. Selain hal tersebut, pada zaman dahulu bentuk-bentuk masjid juga dipengaruhi oleh pendiri atau pemiliknya. Misalnya, jika yang mendirikan orang Tionghoa, maka bentuk arsitektural masjidnya bernuansa Cina; seperti atap lengkung, pewarnaan merah, atau ukiran berbau oriental. Jika yang membangun orang India, maka masjid tersebut bernuansa India. Namun demikian, gaya arsitektur tradisional "atap bersusun" merupakan yang paling populer pada masjid-masjid awal ini.

Pada saat ini, di mana zaman sudah semakin maju, kita melihat sedikit banyak perubahan pada bentuk-bentuk masjid yang ada di Jakarta, baik itu yang berupa penghilangan atau penambahan elemen. Perubahan ini banyak dipengaruhi oleh adanya pergeseran budaya, perkembangan teknologi, serta faktor yang sangat penting, yaitu ketersediaan dana, dan lainnya. Pada masjid modern sendiri perubahan yang paling signifikan adalah penggunaan material. Jika dahulu masjid-masjid tradisional hanya menggunakan material kayu, beton, dinding bata, dan lantai keramik; masjid pada zaman ini banyak menggunakan material beton, baja, marmer, granit, aluminium, dan lain-lain. Sementara bentuk dan desain berada pada urutan berikutnya. Tetapi tidak sedikit juga masjid modern yang mengambil bentuk-bentuk masjid pada awalnya (tradisional), yaitu atap susun tumpang dua seperti Masjid Pondok Indah atau bentuk-bentuk masjid bergaya Timur Tengah seperti masjid Istiqlal, Masjid Al-Azhar, dan Masjid Sunda Kelapa.

Masjid modern dan masjid tradisional di Jakarta mempunyai perbedaan- perbedaan ini dipicu oleh kemajuan zaman yang semakin berkembang. Tetapi elemen-elemen dasar masjid-masjid ini tidak banyak mengalami perubahan, seperti bentuk denah ruang utama masjid yang mayoritas berbentuk persegi. Karena bagaimanapun bentuk masjid, fungsi utamanya tetap, yaitu untuk melaksanakan ibadah shalat.

\section{DAFTAR PUSTAKA}

Ensiklopedia Indonesia. (1990). Jakarta: Cipta Adi Pustaka.

Facebook. (2010). Sejarah Jalan Tambora dan Mesjid Tambora di Jakarta. Diakses dari http://www.facebook.com/note.php?note_id=295152892546.

Gunawan, Hendra. (2011). Masjid Agung Sunda Kelapa, Menteng, Jakarta. Rindu Masjid. Diakses dari http://bujangmasjid.blogspot.com/2011/04/masjid-agung-sunda-kelapa-menteng.html.

Gunawan, Hendra. (2011). Masjid Luar Batang, Penjaringan, Jakarta. Rindu Masjid. Diakses dari http://bujangmasjid.blogspot.com/2011/05/masjid-luar-batang-penjaringan-jakarta.html. 
Hilleribrand, Robert. (1998). Islamic Art and Architecture. London: Thames \& Hudson.

Jakarta.go.id. (2012). As Shalafiah, Masjid. Diakses dari http://www.jakarta.go.id/jakv1/encyclopedia/detail/799.

Kaskus. (2011). Jawa $\quad$ Bag $2 . \quad$ Diakses $\quad$ dari http://www.kaskus.co.id/showpost.php?p=368473592\&postcount=21.

Mesjid Jami Kebon Jeruk. (2009). Artikel Masjid Kebon Jeruk. Diakses dari http://mesjidjamikebonjeruk.blogspot.com/.

Michell, George. (1995). Architecture of the Islamic World: Its History and Social Meaning. London: Thames \& Hudson.

Prihamdani, Dion Shaza. (2011). Cagar Budaya Golongan B. Diakses dari http://dionsarsitektur.blogspot.com/2011/04/cagar-budaya-golongan-b.html.

Sacred Destinations. (2009). Blue Mosque, Istanbul. Diakses dari http://www.sacreddestinations.com/turkey/istanbul-blue-mosque.

Tarekat Qodiriyah. (2011). Masjid Al'Mukaromah Kampung Bandan. Diakses dari http://tarekatqodiriyah.wordpress.com/2011/01/02/masjid-almukaromah-kampung-bandan/.

Wisata Melayu. (2012). Masjid An-Nawier di Pekojan. Diakses dari http://www.wisatamelayu.com/id/tour/594-Masjid-An-Nawier-di-Pekojan/navgeo. 